\title{
Transposisi Arteri Besar dan mutasi gen TBK1
}

\author{
Sri Endah Rahayuningsih \\ Bagian Ilmu Kesehatan Anak RS Hasan Sadikin, Fakultas Kedokteran Universitas Padjadjaran Bandung
}

\begin{abstract}
Latar belakang. Transposisi arteri besar (TAB) adalah suatu penyakit jantung bawaan (PJB) yang termasuk dalam malformasi konotrunkal. Kelainan terasebut ditemukan sekitar 5\% dari seluruh PJB. Seperti pada PJB yang lain penyebab TAB multifaktor yaitu faktor genetik, nongenetik, dan interaksi antara genetik dan nongenetik. Gen TBX1 adalah suatu gen yang termasuk gen faktor transkripsi dan berperan pada pembentukan konotrunkal saat embriogensis jantung. Mutasi pada gen TBX1 akan menyebabkan malformasi konotrunkal.

Tujuan. Mengetahui peran mutasi gen TBX1 pada PJB dengan malformasi konotrunkal.

Metode. Subjek penelitian adalah 42 anak PJB dengan malformasi konotrunkal dan 42 anak tanpa PJB sebagai kontrol, yang memenuhi kriteria inklusi. Deteksi mutasi gen TBX1 dilakukan dengan pemeriksaan sekuensing terhadap isolasi DNA.

Hasil. Ditemukan satu anak dengan mutasi TBX1, mutasi yang terjadi adalah missense mutations dan tempat mutasi terletak pada. Ekson 04 c.614 A>T (p.Gln205Leu). Mutasi ini tidak ditemukan pada kontrol.

Kesimpulan. Ditemukan missense mutation pada TAB, mutasi tidak ditemukan pada kontrol, sehingga TAB pada pasien tersebut diduga akibat mutasi gen TBX1, karena seperti pada PJB yang lain penyebab dari TAB adalah multifaktor. Dengan ditemukannya mutasi gen TBX1 pada TAB, maka hal ini dapat digunakan sebagai bahan konseling genetika. (Sari Pediatri 2009;11(1):21-5).
\end{abstract}

Kata kunci: malformasi konotrunkal, transposisi arteri besar, mutasi, TBX1

$\mathrm{T}$

ransposisi arteri besar (TAB) adalah suatu penyakit jantung bawaan (PJB) yang termasuk dalam malformasi konotrunkal, yaitu terjadi gangguan embriologi pada konotrunkal atau out flow tract ventrikel berupa tertukarnya letak kedua pembuluh darah arteri besar, ${ }^{1}$

\section{Alamat korespondensi}

DR. dr. Sri Endah Rahayuningsih SpA(K). Bagian Ilmu Kesehatan Anak Fakultas Kedokteran Universitas Padjadjaran Jl. Pasteur 38 Bandung 40161 Tlp/Fax. 022-2034426 Email: endah.perkani@gmail.com sehingga aorta keluar dari ventrikel kanan dan arteri pulmonalis dari ventrikel kiri. ${ }^{2-5}$ Ditemukan sekitar 5\% dari seluruh PJB. Pada TAB sirkulasi darah sistemik dan paru terpisah serta berjalan paralel. Kelangsungan hidup bayi yang lahir dengan kelainan ini sangat tergantung pada ada tidaknya percampuran darah balik vena sistemik dan vena pulmonalis yang baik, melalui pirau baik di tingkat atrium (defek septum atrium), ventrikel (defek septum ventrikel), ataupun arteri utama (duktus arteriousus persisten). ${ }^{2-5}$ Sampai saat ini mekanisme terjadinya TAB maupun PJB yang lain masih belum diketahui dengan pasti. 
Penelitian menunjukkan terdapat faktor genetik, faktor lingkungan, dan interaksi antara faktor lingkungan dan genetik yang berperan terhadap terjadinya TAB. ${ }^{6}$

Gen TBX1 adalah suatu gen yang termasuk kelompok $T$ box dan merupakan faktor transkripsi yang terletak pada kromosom 22q11.2, serta terdiri dari 9 ekson. Penelitian sebelumnya menunjukkan gen TBX1 berperan pada morfogonesis konotrunkal saat embriogenesis jantung sehingga mutasi gen TBX1 akan menyebabkan gangguan pada pembentukan kontrunkal 7,8

Tujuan penelitian untuk mengetahui peran mutasi gen TBX1 pada PJB dengan malformasi konotrunkal.

\section{Metode}

Sampel penelitian adalah kasus PJB dengan malformasi konotrunkal, sedangkan kelompok kontrol adalah pasien tanpa adanya PJB yang datang ke instalasi rawat jalan dan instalasi gawat darurat, serta yang dirawat di instalasi rawat inap Bagian Ilmu Kesehatan Anak RS dr. Hasan Sadikin. Diagnosis malformasi konotrunkal dan "tanpa adanya PJB" ditegakkan berdasarkan ekokardiografi oleh dokter konsultan kardiologi anak.

Pasien pada kelompok PJB dengan malformasi konotrunkal dan kelompok kontrol diambil darah vena $5 \mathrm{ml}$, disimpan di dalam tabung EDTA dan dilakukan isolasi DNA di Unit Penelitian Kedokteran FK UNPAD Bandung. Hasil isolasi DNA dibawa ke Department of Human Genetics, Yokohama City University Graduate School of Medicine Jepang untuk

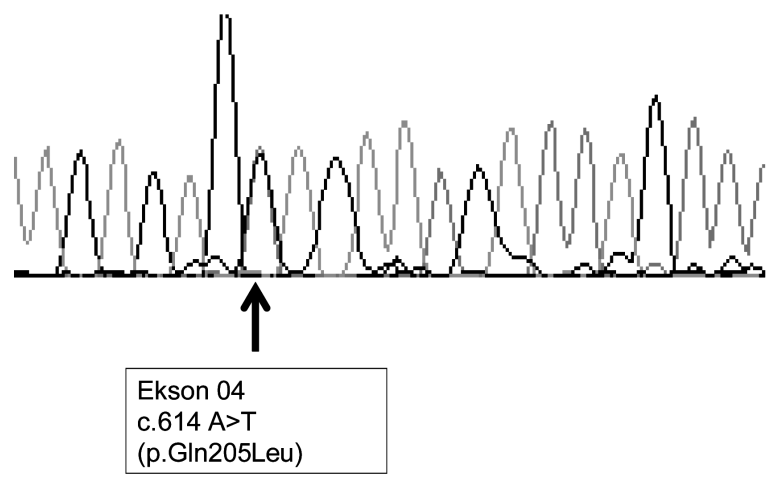

Gambar 1. Mutasi gen TBX1 pada Ekson 04 c.614 A>T (p.Gln205Leu) dilakukan sekuensing DNA. Analisis mutasi dilakukan pada seluruh ekson dengan cara yang terdiri empat tahap yaitu 1) amplifikasi dengan PCR, 2) pemurnian DNA dengan eksosap, 3) sekuensing dengan big dye terminator, dan 4) analisis mutasi sekuensing. Primer yang digunakan terdiri dari 9 primer forward dan reverse berdasarkan literatur sebelumnya., ${ }^{7,8}$ Penelitian dilakukan setelah mendapat persetujuan komisi etik FK UNPAD dan hak cipta penelitian ada pada peneliti Indonesia.

\section{Hasil}

Selama kurun waktu pengumpulan bahan/sampel dari bulan Juli 2006 sampai 30 Juli 2007 di Rumah Sakit Dr Hasan Sadikin Bandung didapatkan 42 anak PJB dengan malformasi konotrunkal dan 42 anak tanpa PJB. Sebelas dari anak PJB adalah TAB, empat belas diantaranya menderita double outlet rght ventricle dan sisanya adalah mempunyai kelainan tetralogy Fallot.

Ditemukan satu anak dengan mutasi TBX1, mutasi yang terjadi adalah missense mutations dan tempat mutasi terletak pada ekson 04c.614 A>T (p.Gln205Leu). Mutasi ini tidak ditemukan pada kelompok kontrol. Mutasi gen TBX1 terjadi pada anak dengan TAB disertai defek septum atrioventrikular. Dilakukan pemeriksaan analisis DNA pada orang tua anak dengan mutasi gen TBX1 dan tidak ditemukan mutasi pada kedua orangtua. Juga dilakukan pemeriksaan ekokardiografi pada kedua orangtua dan tidak terdapat adanya PJB.

\section{Pembahasan}

Malformasi konotrunkal terjadi akibat kegagalan pembentukan konotrunkal pada masa embriologi. ${ }^{1}$ Malformasi konotrunkal yang sering ditemukan adalah transposisi arteri besar, double outlet right ventricle, trunkus arteriousus, atresia pulmonalis dan tetralogy Fallot. ${ }^{2}$ Kegagalan pembentukan konotrunkal terjadi pada 5-6 minggu paska konsepsi, yaitu pada fase looping, septasi dan migrasi. Area konotrunkal terdiri dari dua bagian yaitu daerah konus yang akan menjadi infundibulum dan daerah trunkus yang akan menjadi aorta dan a. pulmonalis., ${ }^{9,10}$ Terdapat beberapa teori yang berbeda yang berusaha menjelaskan terjadinya TAB. Sampai sekarang teori-teori tersebut masih 

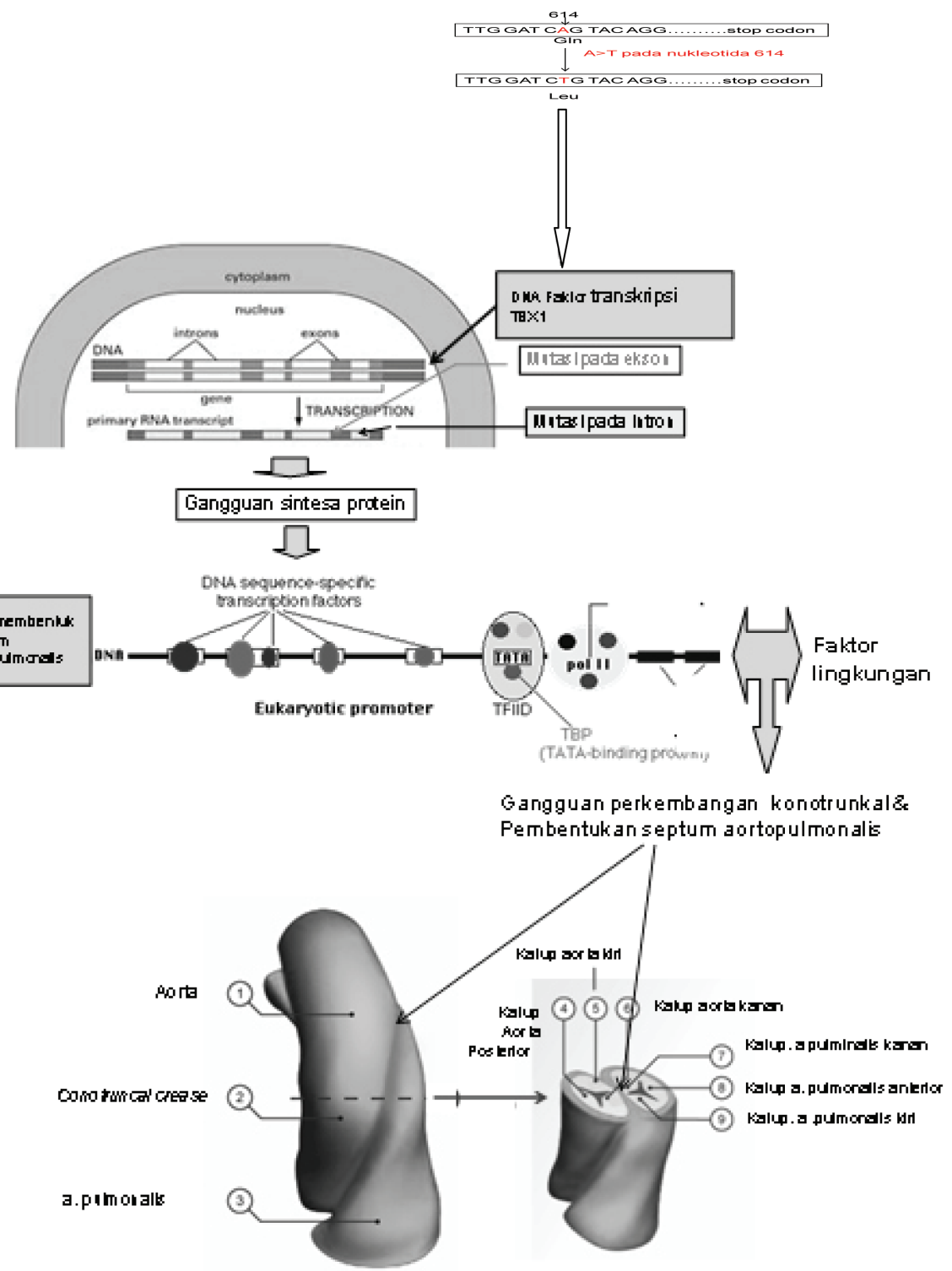

Gambar 2. Mutasi gen TBX1 dan interaksi dengan faktor lingkungan menyebabkan gangguan septasi konotrunkal

dalam perdebatan. Diduga terdapat perkembangan trunkus yang abnormal yaitu ke garis tengah pada fase looping dari konus dan gangguan perkembangan septasi konotrunkal5 (Gambar 2).

Dugaan lain menyatakan bahwa terjadinya $\mathrm{TAB}$ selain akibat proses looping trunkus arteriosus yang abnormal $^{5,6}$ juga disebabkan perkembangan yang abnormal pertumbuhan konus menjadi infundibulum. Pada pertumbuhan jantung normal, infundibulum terletak di bawah katup pulmonal, akibat pertumbuhan infundibulum yang besar, maka katup pulmonal terdapat di anterior superior sedangkan katup aorta terdapat di posterior inferior (Gambar 2). Sebaliknya pada TAB terdapat infundibulum subaortik. Akibat terlalu cepatnya pertumbuhan jaringan infundibulum, maka katup aorta terdapat di anterior superior sedangkan katup pulmonal di posterior inferior. ${ }^{2,5}$ Hipotesis lain menyatakan bahwa TAB terjadi akibat pembentukan septum konotrunkal atau septum aortopulmonal yang abnormal. Pada embriologi 
normal, septasi konotrunkal berlangsung seperti spiral. Sehingga a. pulmonalis akan terletak di anterior dari aorta. Pada TAB septasi seperti spiral ini tidak terjadi. Sehingga a. pulmonalis tidak terletak di anterior, tapi dapat di belakang atau di samping aorta ${ }^{2,5}$

Sampai saat ini belum ada teori yang dapat menjelaskan secara lengkap kelainan anatomi dan posisi abnormal yang bervariasi pada jantung dengan hubungan ventrikuloarterial yang tidak normal. ${ }^{5}$

Kami dapatkan mutasi gen TBX1 pada ekson 04 c.614 A>T (p.Gln205Leu). Terdapat perubahan asam amino glutamine yang merupakan asam amino hidrofilik, polar sehingga lebih mudah berikatan dengan asam amino lain dibandingkan menjadi leucine yang merupakan asam amino hidrofobik non polar. Mutasi yang terjadi adalah heterozigot dan hasil pemeriksaan analisa DNA pada kedua orang tua tidak ditemukan mutasi, maka kemungkinan mutasi gen TBX1 adalah mutasi spontan (de novo). Gen TBX1 merupakan gen faktor transkripsi yang akan mempengaruhi gen lain untuk mensintesa protein yang berperan pada septasi konotrunkal (Gambar 2). Gen TBX1 akan menyandi pembentukan protein T-box, yang terdiri dari 180 asam amino, mempunyai ikatan spesifik DNA yang disebut T. Struktur protein T-box berbentuk dimer pada palindromic DNAbinding site tetapi ada juga yang menyebutkan bahwa protein berikatan sebagai monomer pada setengah palindromic site. Protein T-box berfungsi sebagai aktivator transkripsi, represor, atau keduanya, serta dapat berinteraksi dengan faktor transkripsi lain. Gen T-box dibagi dalam lima subfamili. Beberapa penyakit yang berhubungan dengan mutasi TBX adalah TBX1: Di george/velocardiofacial syndrome; TBX2: $x$ linked cleft palate dengan ankiloglosia; TBX3; ulnar mamarry syndrome; TBX4: small nail patella syndrome; TBX5: berhubungan dengan sindrom Holt Oram.

Pola mutasi gen diklasifikasikan sebagai, a) Missense mutations/nonsynonymous mutations, satu asam amino diganti oleh asam amino lain pada gen target. b) Nonsense mutations, apabila asam amino diganti oleh stop codon. c) Splice site mutations, terbentuk atau adanya kerusakan sinyal terhadap ekson dan intron.

d) Frameshift mutations, dapat disebabkan delesi, insersi, atau spicing. Pada kasus kami, mutasi gen TBX1 yang terjadi adalah missense mutation, sehingga hanya menyebabkan perubahan asam amino glycine menjadi leucine, sedangkan asam amino yang lain tidak berubah. ${ }^{11}$ Mutasi tidak menyebabkan terjadinya stop kodon, yang timbul lebih awal dan akan menyebabkan gangguan pembentukan sintesis protein. Mutasi yang terjadi pada kasus kami terletak pada ekson yaitu bagian asam nukleat yang membawa informasi genetik (Gambar 2). Pola mutasi gen diketahui berdasarkan hasil analisis sekuensing dengan menggunakan perangkat lunak Seq Scape V 2.1.1 dan DNASIS.

Ditemukan mutasi gen TBX1 pada TAB merupakan mutasi spontan, maka merupakan risiko untuk terjadi TAB pada generasi berikutnya. Mengingat mutasi yang ditemukan adalah heterozigot, maka kemungkinan $50 \%$ generasi berikutnya mengalami TAB. Walaupun demikian perlu diperhatikan bahwa TAB merupakan penyakit multifaktor yang disebabkan oleh interaksi antara faktor genetik dan lingkungan, maka missense mutations bersama faktor lingkungan diduga menyebabkan gangguan pembentukan protein yang akan menimbulkan TAB Mutasi gen dan faktor lingkungan yang terjadi akan menyebabkan gangguan pada sintesis protein, yang merupakan faktor transkripsi. Gangguan protein faktor transkripsi akan mengganggu gen penyandi asam amino yang selanjutnya akan mensintesis protein yang berperan pada perkembangan konotrunkal dan septum konotrunkal. Sehingga risiko terjadinya TAB semakin besar bila didapatkan faktor faktor lingkungan selain adanya mutasi gen TBX1

Kekurangan penelitian kami tidak mencari faktor lingkungan penyebab TAB. Penelitian ini merupakan penelitian pertama mutasi gen TBX1 pada PJB di Indonesia.

\section{Kesimpulan}

Ditemukan missense mutation pada TAB tidak ditemukan pada kelompok kontrol. Diduga mutasi gen TBX1 berperan pada terjadinya TAB. Seperti pada PJB, penyebab TAB adalah multifaktor yaitu interaksi antara faktor genetik dan faktor lingkungan. Dengan ditemukan mutasi gen TBX1 pada TAB, dapat digunakan sebagai bahan konseling genetika pada orang tua untuk merencanakan kehamilan berikutnya yang lebih baik.

\section{Ucapan terima kasih}

Penelitian ini mendapat dukungan dana dari Research Grant from the Ministry of Health, Labour and Welfare 
(N. M.) and Grant-in-Aid for Scientific Research on Priority Areas from the Ministry of Education, Culture, Sports, Science and Technology of Japan. Ucapan terimakasih ditujukan kepada Prof Naomichi Matsumoto MD, PhD dan Haruka Hamanoue,MD dari Departments of Human Genetics Yokohama City University Graduate School of Medicine, Yokohama, Japan yang telah membantu melaksanakan sekueunsing DNA.

\section{Daftar pustaka}

1. Praagh RV. Embriology. Dalam: Keane JF, Lock JE, Flyer DC, penyunting. NADAS' pediatric cardiology. Edisi ke-2. Philadelphia: Elsevier Saunders; 2006.h.13-25.

2. Fyler DC. D-Transposition of the great arteries. Dalam: Fyler DC, penyunting. Nadas' pediatric cardiology. Edisi ke 2. Philadelphia: Hanley and Belfus, 2006.h.645-61.

3. Wernovsky G. Transposition of the great arteries. Dalam: Allen HD, Clark EB, Gutgesell HP, Driscoll DJ, penyunting. Moss and Adams' Heart disease in infants, children, and adolescents. Edisi ke-6. Philadelphia: Lippincott Williams and Wilkins, 2001.h.1027-83.

4. Park MK, Troxler RG. Pediatric cardiology for practitioners. Edisi ke-4. St.Louis: Mosby, 2008.h.174-84.

5. Neches WH, Park SC, Ettedgui JA. Transposition of the great arteries. Dalam: Garson A, Bricker JT, Fisher DJ, Neish SR, penyunting. The science and practice of pediatric cardiology. Edisi ke-2. Baltimore: Williams and Wilkins; 1998.h.1463-503.

6. Clark EB. Etiology of congenital cardiovascular malformations: epidemiology and genetics. Dalam: Allen HD, Gutgesell HP, Clark EB, Driscoll DJ, penyunting. Moss and Adam's heart disease in infants, children, and adolescents. Edisi ke-6. Philadelphia: William and Wilkins; 2001.h.64-79.

7. Xu H, Morishima M, Wylie JN, Schwartz RJ, Bruneau BG, Lindsay EA and Baldini A. TBX1 has a dual role in the morphogenesis of the cardiac outflow tract. Development 2004;131:3217-27

8. Rauch A, Devriendt K, Koch A, Rauch R, Gewillig M, Kraus C, Weyand M, Singer H, Reis A, Hofbeck M. Assessment of association between variants and haplotypes of the remaining TBX1gene and manifestations of congenital heart defects in 22q11.2 deletion patients. J Med Genet 2004;41:e40

9. Gittenberger-de Groot AC, Bartelings MM, Deruiter MC, Poelmann RE. Basics of cardiac development for the understanding of congenital heart malformations. Ped Res 2005;57:169-76.

10. Lamers WH, Moorman AFM. Cardiac septation: a late contribution of the embryonic primary myocardium to the heart morphogenesis. Circ Res. 2002;91:93-103.

11. Strachan T, Read AP. Human molecular genetics. Edisi ke-3. New York: Garland Science; 2004.h.463-5 